\title{
НОТАРИАЛЬНАЯ ДЕЯТЕЛЬНОСТЬ КАК ВИД ЮРИДИЧЕСКОЙ ДЕЯТЕЛЬНОСТИ И ЕЕ ФУНКЦИИ
}

\section{NOTARIAL ACTIVITY AS A TYPE OF LEGAL ACTIVITY AND ITS FUNCTIONS \\ O. Filippova}

Summary. Notarial activity in legal Sciences is revealed from the point of view of the legal status of notary activity in the legal system, which is reflected in the works of B.M. Gongalo, A.O. Inshakova, V.V. Ralko, N. V. Repin, A. Ya. Ryzhenkova, Yu. A. Tymchuk, O. V. Filippova, A. B. Tsarelungo, I. G. Cheremnykh, V.V. Yarkov, and others. On the other hand, it is necessary to study the psychological content of notarial activity from the position sistemogenetichesky approach adopted in the domestic psychological science, revealing the structural-psychological features of professional activity of the notary (M.I. Enikeev, E. F. Zeer, N. In. Nizhegorodtsev, P. Povarenkov, I. N. Sorokotyagi, A. M. Stolyarenko, V. D. Shadrikov etc.).

Notarial activity in the legal Sciences is defined as one of the most significant areas of legal activity, the emergence and development of which is due to the objective need to assist citizens in the formal legal consolidation of actions and legal claims, ensuring their evidence and legality.

Keywords: notary activity, functions of a notary, legal science, guarantor of legal security, notary, notary profession, jurisdiction.

\author{
Филиппова Ольга Владимировна \\ К.ю.н., доцент, Уральский институт «Всероссийский \\ государственный университет юстиции (РПА \\ Минюста России)»; член Российской криминологической \\ ассоциации, Нотариус г. Екатеринбурга \\ ovz24@ya.ru
}

Аннотация. Нотариальная деятельность в правовых науках раскрывается с точки зрения правового статуса деятельности нотариата в юридической системе, что нашло отражение в работах Б. М. Гонгало, А.О. Иншаковой, В. В. Ралько, Н. В. Репина, А. Я. Рыженковой, Ю. А. Тымчук, О. В. Филипповой, А. Б. Царелунго, И.Г. Черемных, В.В.Яркова и др. С другой стороны, необходимым является исследование психологического содержания нотариальной деятельности с позиции системогенетического подхода, принятого в отечественной психологической науке, позволяющего раскрыть структурно-содержательные психологические особенности профессиональной деятельности нотариуса (М.И. Еникеев, Э.Ф.Зеер, Н.В.Нижегородцева, Ю. П. Поваренков, И. Н. Сорокотягин, А. М. (толяренко, В. Д. Шадриков и др.).

Нотариальная деятельность в правовых науках определяется как одна из значимых сфер юридической деятельности, возникновение и развитие которой обусловлено объективной необходимостью содействовать гражданам в формально-юридическом закреплении действий и законных притязаний, обеспечивая их доказательность и правомерность.

Ключевые слова: нотариальная деятельность, функции нотариата, правовая наука, гарант юридической безопасности, нотариус, нотариальная профессия, юрисдикция.

некоммерческую публичную нотариальную деятельность, обладая необходимыми для этого правами и обязанностями» [8].

Профессию нотариуса, по мнению Б.М. Гонгало и соавт.[2], отличает целый ряд признаков в отличие от представителей других юридических профессий, к которым ученые относят:

- деятельность в сфере доказательственного права по обеспечению квалифицированных доказательств в сфере гражданского оборота;

- нотариальная деятельность в системе органов гражданской юрисдикции осуществляется в несостязательной сфере бесспорной юрисдикции;

- особый доступ к нотариальной профессии, связанный с повышенными квалификационными требованиями к нотариусу и характеру его подготовки к исполнению своей профессии, который связан с получением дополнительного образо- 
вания и практических навыков, не охватываемых общим стандартом высшего юридического образования;

- осуществление нотариусом публично-правовых функции от имени государства - Российской Федерации, что отражает его правовой статус как лица, находящегося на службе государства и общества;

- нотариусов, занимающихся частной практикой, характеризует работа в режиме самофинансирования и самостоятельная организация своей деятельности при условии подотчетности и подконтрольности, как государственным органам, так и органам нотариального сообщества;

- презумпция знания законодательства РФ в профессии нотариуса, что определяет повышенные требования к уровню его квалификации;

- необходимость определенных психологических характеристик и соблюдения режима ряда личных ограничений как правового, так и этического свойства.

Таким образом, профессия нотариуса объединяет черты самых различных юридических профессий, интегрируя в себе специфику нотариальной деятельности.

Деятельность нотариата в настоящее время в РФ регулируется Основами законодательства РФ о нотариате от 11.02.1993 № 4462-1. Законодательство о нотариате в РФ с 2013 года подверглось реформированию, содержание которого отражено в Федеральном законе от 21 декабря 2013 г. № 379-Ф325, Федеральном законе от 29 декабря 2014 г. № 457-Ф326, Федеральном законе от 29 декабря 2015 г. № 391-Ф327. Нововведения были направлены на увеличение полномочий нотариуса и рост привлекательности нотариальной формы совершаемых сделок в области гражданского оборота недвижимости, на образование условий для тесного взаимодействия нотариата с выстроенной системой государственной регистрации прав для обеспечения устойчивости гражданского оборота недвижимости[3]. Расширение профессиональных полномочий нотариуса, в свою очередь, предъявляет и ряд новых профессиональных требований к личности нотариуса как субъекту нотариальной деятельности.

Каковы цели и задачи профессиональной деятельности нотариуса с позиции ее правового статуса? Согласно нормативному толкованию задачей профессиональной деятельности нотариуса является осуществление защиты прав и законных интересов граждан и юридических лиц путем совершения предусмотренных законодательными актами нотариальных действий от имени Российской Федерации. Нотариальная деятельность в правовой литературе определятся аналогичным образом «как дея- тельность нотариусов, которая осуществляется от имени государства на возмездной основе для совершения защиты прав, а также законных интересов физических и юридических лиц, которая заключается в выполнении нотариальных действий, предусмотренных действующим российским законодательством» [4]. Нотариальную деятельность, ученые определяют как «урегулированную законодательством деятельность нотариусов и иных уполномоченных государством лиц по совершению нотариальных действий с целью защиты прав и законных интересов граждан и юридических лиц, общества и государства» [7]. Таким образом, субъектами нотариальной деятельности могут являться как нотариусы, так и другие должностные лица, выполняющие нотариальные функции и совершающие нотариальные действия, оказывая правовую помощь населению и содействуя защите их законных интересов. Субъектами нотариальной деятельности, согласно законодательству, могут быть нотариусы, работающими в государственных нотариальных конторах, нотариусы, ведущие частную практику, должностные лица органов исполнительной власти, консульских учреждений, а также иных уполномоченных лиц.

Нотариальная деятельность по своему содержанию и структуре является сложным многокомпонентным образованием, в которое входят различные по составу функциональные блоки и виды нотариальных действий. Нотариат, функционируя на грани публичных и частных интересов, по мнению Г.Г. Черемных, И.Г. Черемных, реализует следующие категории функций нотариальной деятельности:

1. функции, отражающие публично-правовой характер нотариальной деятельности, при котором нотариат выступает как орган, который наделен государственно-властными полномочиями: правоохранительная функция, правоприменительная, предупредительно-профилактическая функции;

2. функции, отражающие частно-правовое содержание осуществляемой нотариальной деятельности в сфере гражданского оборота, рассматривающие содержательную сторону осуществляемой нотариальной деятельности в отношении субъектов нотариального производства: правореализующая функция, правоустановительная и консультационная функции[9].

Б.М. Гонгало и соавт.[2] утверждают, что нотариальные функции носят в целом особый характер, отражая специфику нотариального производства и нотариальной деятельности в сфере гражданского оборота. Функции нотариата авторы подразделяют на:

1. социальные, характеризующие место нотариата в системе органов гражданской юрисдикции и правовой системе РФ: предупредительно-про- 
филактическая; правореализационная; правоохранительная; фискальная;

2. содержательные, отражающие характер нотариальной деятельности, связанные с правоустановительной, удостоверительной, охранительной и юрисдикционной деятельностью.

Ряд авторов функции нотариата трактуют как функции превентивного правосудия. По их мнению, нотариат выступает институтом превентивного, предупредительного правосудия со своей подведомственностью и формами деятельности[1]. Превентивная функция нотариата обеспечивает предупреждение и разрешение правовых споров. С этой целью нотариальная деятельность может быть организована в двух направлениях: во-первых, в виде непосредственного обеспечения защиты прав и свобод человека и гражданина, что исключает необходимость обращаться в суд; во-вторых, в виде защиты прав частных и публичных субъектов правоотношений на стадии судебного процесса, когда обращение в суд неизбежно. Инновационным является возможность участия нотариуса в процедурах медиации, которые являются новым явлением в отечественной правовой науке и практике. Внедрение процедур медиации в нотариальную практику предполагает определение роли нотариуса как независимого советника сторон; фиксирование прав нотариуса по оказанию юридической помощи по урегулированию разногласий сторон в рамках совершаемого нотариального действия; формирование и закрепление процедуры медиации как одного из видов нотариального действия.
Анализ нотариальных функций показывает их тесную взаимосвязь и системное воздействие на нотариальную деятельность, а также наличие в нотариальном праве как охранительных, так и существенных позитивных характеристик, отражающих правосозидательную силу нотариата. Система нотариальных функций определяет наличие полномочий, которые предоставляются нотариусам для исполнения ими нотариальных действий, связанных с контролем и проверкой, с разъяснением и удостоверением сделок.

Нотариальные функции оказывают влияние на состав и характер осуществляемых нотариальных действий по контролю, по удостоверению и формированию квалифицированных доказательств, по консультированию сторон совершаемой сделки, предупреждению применения правовой неграмотности во вред интересов сторон сделок. Нотариальные действия обладают следующими специфическими признаками, выделенными О.В. Филипповой: могут производиться только специальным субъектом; их перечень, дифференцированный в зависимости от субъекта нотариальной деятельности, определен в законе; совершаются в строго определенной процессуальной форме; их содержание должно основываться на положениях действующего законодательства; считаются совершенными после уплаты государственной пошлины или тарифа[7]. Как отмечает И.Н. Сорокотягин, «все подвиды нотариальной деятельности взаимосвязаны и взаимообусловлены, поэтому провести четкую грань между ними довольно сложно» [6].

\section{ЛИТЕРАТУРА}

1. Глухова, 0. Ю. Нотариат как институт превентивного правосудия / 0. Ю. Глухова // ХІХ Державинские чтения. Институт права: материалы 0бщероссийской научной конференции. Февраль 2014 года. - Тамбов: Издат. дом ТГУ им. Г. Р. Державина, 2014. — C. 236-240

2. Гонгало, Б.М., Зайцева, Т.И., Крашенинников, П.В., Юшкова, Е.Ю., Ярков, В. В. Настольная книга нотариуса. Учебно-методическое пособие. 2-е изд., испр. и доп. - М.: Изд-во «Волтерс Клувер», Т. 1. - 2004. - 574 с.

3. Иншакова А.О., Тымчук Ю. А. Обязательное нотариальное удостоверение сделок с недвижимостью как Гарант стабильности ее гражданского оборота / А. О. Иншакова, Ю. А. Тымчук // Вестник ВолГУ. Серия 5: Юриспруденция.— 2016. № 2 (31). — С. 125-133.

4. Калиниченко, Т. Г. Нотариальное право и процесс в Российской Федерации: теоретические вопросы развития: монография / Т. Г. Калиниченко.- 2-е изд., перераб. и доп.- Москва: Норма: ИНФРА-М, 2012.-С. 19.

5. Нотариат: учебник / В. В. Ралько, Н. В. Репин, А. В. Дударев, В. А. Фомин.— М.: Юстиция, 2016.— С. 13.

6. Сорокотягин, И. Н. Юридическая психология: учебник и практикум для академического бакалавриата /И.Н. Сорокотягин, Д. А. Сорокотягина. - 4-е изд., перераб. и доп. - М.: Издательство Юрайт, 2017. - С. 322.

7. Филиппова, 0. В. Уголовно-правовое обеспечение нотариальной деятельности в России: диссертация ... кандидата юридических наук: 12.00 .08 / Филиппова Ольга Владимировна.— Екатеринбург, 2011. — С. 11.

8. Царелунго А.Б Правовой статус нотариуса в Российской Федерации: диссертация ... кандидата юридических наук: 12.00.11 / Царелунго Александр Борисович.- М., 2006. - $28 \mathrm{c}$.

9. Черемных, Г. Г. Нотариальное право РФ: учебник / Г. Г. Черемных, И. Г. Черемных; под ред. Ю. А. Дмитриева. — 2-е изд., перераб. и доп. — Москва: Эксмо, 2006. - $714 c$.

10. Черемных, И. Г. Теоретические основы независимого нотариата России / И. Г. Черемных. — Москва: Буквовед, 2006. — С. 31. 